\title{
Türkiye’de Kadın İşgücünün Görünümü ve Büyümeye Etkisi $(2008-2018)^{1}$
}

\author{
An Outlook Of Female Labour Work Force And Its Impact On Economic Growth In \\ Turkey (2008-2018)
}

\author{
Sevil TAŞ* \\ Bilge AFŞAR** \\ Erkan $K A R A^{* * *}$
}

Ekonomik büyüme, ekonomilerde ana hedeflerden biridir. Kalkınma ve refah seviyesinin artırlması için ekonomik aktivitelerin de artış göstermesi gerekir. Kıt kaynakların doğru bir şekilde değerlendirilmesi, teknolojiye yönelik olarak sermayenin artışı ve bunların yanında emek faktörünün rasyonel kullanımı ekonomik büyümenin sürekliliğini sağlamaktadır. Fakat yoksulluk, gelir dağllımındaki adaletsizlik ve işsizlik gibi sorunlar çözüme ulaşamamıştır. Bu sorunlar kadın işgücü üzerinde de olumsuz etkiler bırakmaktadır. Ekonomik büyüme ve kalkınmada insan faktörü vazgeçilmez bir ögedir. Bu yüzden nüfusun yaklaşık yarısını oluşturan kadın emeği olmadan bir ülkede kalkınmadan bahsedilemez. Kadınların mevcut konumlarını kuvvetlendirmek de ekonominin amaçları arasındadır.

Bu kapsamda çalışmanın temel amacı, Türkiye’ de kadın işgücünün genel görünümünü vermek ve kadın istihdamı ile ekonomik büyüme arasındaki uzun dönemli ilişkiyi ekonometrik analizlerle incelemektir. Ayrıca büyüme ve kadın istihdamı değişkenler arasındaki nedensellik ilişkisini ortaya çıkarmaktır. Kadın istihdamı ve ekonomik büyüme arasındaki uzun dönemli ilişki ARDL eşbütünleşme testi ve hata düzeltme modeli uygulanarak bulunmuştur. Analiz sonuçları kısa dönemde kadın istihdamı ile ekonomik büyüme arasında pozitif bir ilişkiyi, uzun dönemde ise bu ilişkinin yönünün negatif olduğunu ortaya koymuştur. Uygulanan nedensellik testinde ise değişkenlerin birbirlerinin nedeni olmadı̆̆l görülmüştür.

\section{ANAHTAR KELIMELER}

Kadın İsgücü, Ekonomi, Ekonomik Büyüme

\begin{abstract}
The concept of economic growth is one of the main objectives of the economies of all countries. In order to increase the level of development and prosperity in economies, economic activities should also increase. Utilization of scarce resources, increase in capital for technology and the rational use of labor factors ensure continuity of economic growth. On the other hand, problems such as poverty, inequality in income distribution and unemployment have not been solved enough. All these problems had the most negative effects on female labor force. Since human factor is an indispensable element in economic growth and development, sustainable growth in economies cannot be done in a country without women's labor work force, which makes up about half of a country's population. Strengthening the existing position of female participants should be among the priorities for economies.

The main objective of this work in this scope, is to provide overall view of female work force in Turkey and examine a long-term relationship between female employment and economic growth by econometric analysis and finally to uncover the causal relationship between these variables. The long-term relationship between female employment and economic growth was found by applying ARDL cointegration test and error correction model. While the results of the analysis found a positive relationship between female employment and economic growth in the short term, the direction of this relationship was found to be negative in the long run. In the causality test, there seems to be no causality between none of the variables.
\end{abstract}

KEYWORDS

Female Labor Force, Economics, Economic Growth

\begin{tabular}{|c|c|c|}
\hline & $\begin{array}{l}\text { Makale Geliş Tarihi / Submission Date } \\
\text { 24.08.2020 }\end{array}$ & $\begin{array}{c}\text { Makale Kabul Tarihi / Date of Acceptance } \\
07.10 .2020\end{array}$ \\
\hline Atıf & \multicolumn{2}{|c|}{$\begin{array}{l}\text { Taş, S., Afşar, B. ve Kara, E. (2020). Türkiye'de Kadın İşgücünün Görünümü ve Büyümeye Etkisi (2008-2018). } \\
\text { Selçuk Üniversitesi Sosyal Bilimler Meslek Yüksekokulu Dergisi, } 23 \text { (2), 590-602. }\end{array}$} \\
\hline
\end{tabular}

\footnotetext{
${ }^{1}$ Bu makale Doç. Dr. Bilge AFŞAR danışmanlığında, Sevil TAŞ tarafından hazırlanmış yüksek lisans tezinden üretilmiştir.

*karasevile@gmail.com, ORCID: 0000-0002-7179-6726

** Doç. Dr., KTO Karatay Üniversitesi, bilge.afsar@karatay.edu.tr, ORCID: 0000-0002-2891-7617

*** Dr. Öğr. Üyesi, Necmettin Erbakan Üniversitesi, erkankaralar@hotmail.com, ORCID: 0000-0001-7228-0396
} 


\section{GİRIŞ}

Bir ülkenin ekonomik büyümesi, "zaman içinde çeşitlenen üretim mallarını üretme kapasitesindeki uzun süreli artış, teknolojiye dayalı olarak artış gösteren kapasite ve kurumsal düzenlemeler" şeklinde tanımlanabilmektedir (Kuznets, 1973: 247). Ekonomik büyüme, kadınların ev içinde yaptığı işleri hafifleterek, daha çok boş zaman yaratıp, onlara işgücüne katılma şansı sunabilmektedir. Bunun dışında, erkeklerin kendi işlerini hafifletmelerine ve pazar haricindeki etkinliklerde daha fazla zaman geçirmesine imkân sağlamaktadır (World Bank, 2001). Kadınların işgücüne dâhil olmasını etkileyen eğitim gibi pek çok unsur vardır. Gelişmekte olan ülkelerin büyük bir kısmında, kadınlar, işgücünde yeterli miktarda temsil edilmemektedir. Sürdürülebilir kalkınma hedefleri kapsamında eşit şartlarda eğitim vermek, hayat boyunca öğrenme imkânını teşvik etmek, cinsiyet eşitsizliğini ortadan kaldırmak, kadınları güçlendirmek, ekonomi politikası oluşturmak amacıyla gerekli hedeflerdir. Sürdürülebilir gelişme, büyümenin anahtarı konumundadır. İktisadi olmayan çalışmaları arasında ev işleri ve çocuk büyütme olan kadınlar sahip olunan beşerî sermayenin yarısını meydana getirmektedir. Bölgesel ve küresel çapta sürdürülebilir bir büyüme, kadınların becerileri ve sahip olduğu niteliklerinin baştan sona kullanılmasına ve işgücüne dahil olmalarına bağlıdır. Kadın ve erkek arasındaki eşitsizliklerin ortadan kaldırılması ve kadınların işgücüne dâhil olma oranlarının artmasıyla, kadınların işgücünde aktif rol oynaması ekonomik büyümeyi, gelir eşitsizliği durumunu, toplumsal refahı, kişi başına düşen milli geliri, mesleki performansı ve yeniliği iyileştirmekte ve arttırmaktadır.

\section{DÜNYADA VE TÜRKIYY'DE KADIN İŞGÜCÜNÜN GÖRÜNÜMÜ}

Günümüz dünyasında, özellikle son yıllarda oluşan globalleşme ve getirdiği sık1 rekabet, teknolojik gelişmeler ve eğitim, istihdam alanında önemli değişmelere sebep olmuştur. Dünya, hızlı bir biçimde gelişen bir teknoloji ile bilişim çağını yaşamaktadır. Global rekabet, birçok beceriye sahip, rekabet etmeyi seven ve hayat boyu öğrenmeye açık işgücüne ihtiyacı çoğaltmıştır.

Türkiye'de işgücü ve istihdamın önemini ve niteliğini belirleyen başlıca sebepler arasında, nüfusun hızla çoğalması, gelir dağılımındaki eşitsizlik, bölgeler arasındaki gelişme dengesizlikleri, eğitim ve öğretim uygulamaları ve yatırım politikalarındaki stratejiler bulunmaktadır. Türkiye gibi gelişmekte olan ülkelerde kadın istihdamı oluşturmanın yolu, makroekonomik sürdürülebilirlikle gelen büyümeden geçmektedir. Büyüme olmazsa istihdam oranı yükselmez ve hatta düşme eğilimine girebilir. Kadın istihdamını arttıracak bir büyüme ve gelişme için, yapısal niteliklerini belirlemek ve geliştirmek gerekmektedir. Türkiye'nin ekonomik sorunlarından bir tanesi de kadın işgücüne yeterli istihdam olanaklarının sağlanamamasıdır. Ayrıca nüfus artış hızının gerisinde yeni yatırım ve iş imkânları, kadın işgücü piyasasını negatif yönlü olarak etkilemekte, çalışan nüfusun ekonomik olarak aktif nüfusa olan oranını düşürmektedir (Bağdadioğlu, 2008: 20).

\subsection{Dünyada Kadınların İşgücüne Katılım Oranları}

İş bulmaya çalışanların ve hali hazırda çalışanların toplamı, çalışabilecek durumdaki yaşa gelmiş olan toplam nüfusa oranı, işgücüne katılım oranı sonucunu verir. Çalışılabilecek yaştaki nüfus tanımı bütün ülkeler için küçük farklıklar gösterse de genellikle 15-64 yaş aralığındadır. Dünya genelinde işgücüne katılım oranını inceleyen çalışmaların sonuçları iki maddede özetlenebilir. Bu maddelerden ilki, kadınların işgücüne katılma oranının zamanla arttığını, ikincisi ise, kadınlardaki bu oranların yükselmesinin aksine erkeklerde bu oranın sabit kaldığı veya kadınların oranı kadar artmadığııı ifade etmektedir. Tablo 1'de tüm dünyada kadın ve erkek işgücüne katılım oranları verilmiştir (Peterson, 2016). Tablo 1 verilerine göre Dünya kadın istihdamının özellikle 2006 sonrasında düşme eğilimi gösterirken, erkek işgücünün de benzer bir eğilim içinde olmuş ve toplam işgücü istihdamıdaki azalış ile parallellik göstermiştir.

Son yıllarda istihdamın azalmasının bir nedeni de üretimde görülen otomasyon ve teknolojik gelişmelerdir (Mokyr ve ark, 2015).

Tablo 1. Dünya Çapında İşgücüne Katılım Oranları (\%)

\begin{tabular}{|l|lllllllllllllll|}
\hline Yllar & $\mathbf{1 9 9 0}$ & $\mathbf{1 9 9 1}$ & $\mathbf{1 9 9 2}$ & $\mathbf{1 9 9 3}$ & $\mathbf{1 9 9 4}$ & $\mathbf{1 9 9 5}$ & $\mathbf{1 9 9 6}$ & $\mathbf{1 9 9 7}$ & $\mathbf{1 9 9 8}$ & $\mathbf{1 9 9 9}$ & $\mathbf{2 0 0 0}$ & $\mathbf{2 0 0 1}$ & $\mathbf{2 0 0 2}$ & $\mathbf{2 0 0 3}$ & $\mathbf{2 0 0 4}$ \\
\hline Kadın & 55.8 & 55.8 & 55.9 & 55.8 & 55.9 & 55.8 & 55.8 & 55.7 & 55.6 & 55.7 & 55.6 & 55.4 & 55.3 & 55.2 & 55.1 \\
Erkek & 80.1 & 80.0 & 79.9 & 79.7 & 79.6 & 79.4 & 79.2 & 79.0 & 78.8 & 78.7 & 78.5 & 78.1 & 77.9 & 77.6 & 77.4 \\
Toplam & 70.2 & 70.2 & 70.2 & 70.1 & 70.0 & 69.8 & 69.8 & 69.7 & 69.6 & 69.6 & 69.4 & 69.2 & 69.0 & 68.8 & 68.7 \\
\hline Yllar & $\mathbf{2 0 0 5}$ & $\mathbf{2 0 0 6}$ & $\mathbf{2 0 0 7}$ & $\mathbf{2 0 0 8}$ & $\mathbf{2 0 0 9}$ & $\mathbf{2 0 1 0}$ & $\mathbf{2 0 1 1}$ & $\mathbf{2 0 1 2}$ & $\mathbf{2 0 1 3}$ & $\mathbf{2 0 1 4}$ & $\mathbf{2 0 1 5}$ & $\mathbf{2 0 1 6}$ & $\mathbf{2 0 1 7}$ & $\mathbf{2 0 1 8}$ & \\
\hline Kadın & 55.0 & 54.7 & 54.5 & 54.1 & 53.8 & 53.4 & 53.1 & 52.9 & 52.9 & 52.9 & 53.0 & 53.1 & 53.2 & 53.1 & \\
Erkek & 77.3 & 77.0 & 76.8 & 76.6 & 76.3 & 76.0 & 75.8 & 75.7 & 75.6 & 75.4 & 75.3 & 75.1 & 75.0 & 74.9 & \\
Toplam & 68.6 & 68.3 & 68.1 & 67.9 & 67.6 & 67.3 & 67.1 & 67.0 & 67.0 & 66.9 & 66.9 & 66.9 & 67.0 & 66.9 & \\
\hline
\end{tabular}

Kaynak: http:www.ilo.org 
Tablo 2. Bazı Gelișmiș Ülkelerde 15 Yaș Üstü Toplam İstihdam ve Bu İstihdam İçindeki Kadın Ve Erkek İstihdam Oranları (\%)

\begin{tabular}{|c|c|c|c|c|c|c|c|c|c|c|c|c|c|c|c|c|c|c|c|c|c|}
\hline \multirow[b]{2}{*}{ Yillar } & \multicolumn{3}{|c|}{ Avustralya } & \multicolumn{3}{|c|}{ Avusturya } & \multicolumn{3}{|c|}{ Canada } & \multicolumn{3}{|c|}{ Almanya } & \multicolumn{3}{|c|}{ İspanya } & \multicolumn{3}{|c|}{ Fransa } & \multicolumn{3}{|c|}{ Yunanistan } \\
\hline & Kadın & Erkek & Toplam & $\operatorname{adın}$ & Erkek & Toplam & Cadın & Erkek & Toplam & $\operatorname{adin}$ & rkek & Toplam & Kadın & Erkek & Toplam & adın & Erkek & Toplam & adın & Erkek & Toplam \\
\hline 1995 & 53.60 & 73.81 & 63.54 & 9.38 & 70.47 & 59.43 & 57.48 & 72.46 & 64.82 & 47.68 & 68.57 & 57.72 & 36.80 & 64.20 & 50.05 & 48.22 & 63.40 & 55.44 & 35.47 & 64.39 & 49.20 \\
\hline 1996 & 53.79 & 73.58 & 63.52 & 48.82 & 69.81 & 58.83 & 57.47 & 72.17 & 64.67 & 47.85 & 68.16 & 57.61 & 37.32 & 64.26 & 50.35 & 48.60 & 63.66 & 55.77 & 36.56 & 4.17 & 49.66 \\
\hline 1997 & 53.58 & 73.00 & 63.12 & 48.72 & 69.10 & 58.44 & 57.79 & 72.23 & 64.87 & 48.18 & 67.85 & 57.67 & 38.08 & 64.40 & 50.81 & 48.27 & 63.32 & 55.45 & 36.20 & 62.89 & 48.85 \\
\hline 1998 & 53.64 & 72.70 & 63.00 & 49.34 & 69.28 & 58.85 & 58.38 & 72.12 & 65.13 & 48.41 & 67.62 & 57.68 & 38.42 & 64.62 & 51.10 & 48.59 & 63.00 & 55.46 & 39.44 & 65.42 & 52.06 \\
\hline 1999 & 53.63 & 72.24 & 62.76 & 49.52 & 69.38 & 58.99 & 58.91 & 72.39 & 65.53 & 48.97 & 67.38 & 57.87 & 39.12 & 64.93 & 51.61 & 48.92 & 63.23 & 55.75 & 40.37 & 65.03 & 52.36 \\
\hline 2000 & 54.51 & 72.09 & 63.14 & 49.42 & 68.90 & 58.71 & 59.40 & 72.35 & 65.76 & 48.86 & 66.66 & 57.46 & 40.70 & 65.58 & 52.77 & 49.08 & 62.94 & 55.70 & 40.38 & 64.88 & 52.29 \\
\hline 2001 & 55.05 & 71.86 & 63.30 & 49.37 & 67.93 & 58.24 & 59.75 & 72.27 & 65.91 & 49.29 & 66.20 & 57.48 & 39.56 & 65.34 & 52.09 & 48.86 & 62.71 & 55.50 & 39.58 & 64.13 & 51.54 \\
\hline 2002 & 55.24 & 71.79 & 63.36 & 50.66 & 68.11 & 58.96 & 60.91 & 73.01 & 66.86 & 49.36 & 65.69 & 57.27 & 42.13 & 66.03 & 53.77 & 49.07 & 62.94 & 55.72 & 40.12 & 64.12 & 51.80 \\
\hline 2003 & 55.91 & 71.54 & 63.59 & 50.80 & 68.24 & 59.15 & 61.89 & 73.41 & 67.56 & 49.74 & 65.37 & 57.32 & 43.62 & 66.79 & 54.94 & 50.32 & 63.06 & 56.41 & 40.78 & 64.36 & 52.24 \\
\hline 2004 & 55.69 & 71.51 & 63.46 & 50.02 & 65.13 & 57.26 & 61.99 & 73.17 & 67.49 & 49.43 & 64.74 & 56.87 & 45.01 & & & 0.14 & 62.94 & 56.25 & 42.09 & 64.51 & 52.99 \\
\hline 2005 & 56.97 & 72.09 & 64.40 & 51.30 & 66.40 & 58.56 & 61.66 & 72.80 & 67.14 & 51.10 & 66.15 & 58.42 & 46.49 & 68.10 & 57.09 & 50.46 & 62.57 & 56.24 & 42.14 & 64.30 & 52.90 \\
\hline 2006 & 57.52 & 72.24 & 64.76 & 51.99 & 66.74 & 59.08 & 61.88 & 72.32 & 67.02 & 51.98 & 66.32 & 58.96 & 47.91 & 68.37 & 57.95 & 50.53 & 62.32 & 56.15 & 42.44 & 64.35 & 53.08 \\
\hline 2007 & 58.07 & 72.51 & 65.18 & 52.85 & 67.57 & 59.94 & 62.51 & 72.54 & 67.44 & 52.41 & 66.25 & 59.15 & 48.96 & 68.53 & 58.58 & 50.90 & 62.17 & 56.28 & 42.35 & 64.16 & 52.93 \\
\hline 2008 & 58.55 & 72.62 & 65.48 & 53.39 & 67.47 & 60.17 & 62.55 & 72.73 & 67.56 & 52.52 & 66.31 & 59.24 & 50.35 & 68.69 & 59.37 & 51.10 & 62.13 & 56.37 & 42.42 & 64.17 & 52.98 \\
\hline 2009 & 58.75 & 72.30 & 65.43 & 54.05 & 67.32 & 60.45 & 62.43 & 71.91 & 67.09 & 52.92 & 66.19 & 59.39 & 51.45 & 67.82 & 59.50 & 51.45 & 62.20 & 56.58 & 43.50 & 64.03 & 53.45 \\
\hline 2010 & 58.61 & 72.36 & 65.39 & 54.16 & 67.10 & 60.40 & 62.41 & 71.56 & 66.91 & 53.06 & 66.07 & 59.37 & 52.16 & 67.34 & 59.61 & 51.46 & 62.04 & 56.51 & 44.08 & 63.56 & 53.50 \\
\hline 2011 & 58.86 & 72.17 & 65.42 & 54.51 & 66.90 & 60.49 & 62.16 & 71.40 & 66.71 & 54.01 & 66.54 & 60.09 & 52.82 & 66.82 & 59.68 & 51.33 & 61.66 & 56.26 & 43.78 & 62.17 & 52.66 \\
\hline 2012 & 58.77 & 71.73 & 65.15 & 55.00 & 66.93 & 60.76 & 62.13 & 71.02 & 66.50 & 54.03 & 66.44 & & 53.44 & & 59.75 & & & 56.47 & 43.98 & 61.28 & 52.33 \\
\hline 2013 & 58.68 & 71.39 & 64.94 & 55.29 & 66.93 & 60.92 & 62.17 & 70.87 & 66.46 & 54.59 & 66.42 & 60.35 & 53.38 & 65.62 & 59.36 & 51.73 & 61.58 & 56.44 & 43.75 & 60.91 & 52.03 \\
\hline 2014 & 58.65 & 70.95 & 64.70 & 55.31 & 66.43 & 60.69 & 61.55 & 70.56 & 65.99 & 54.77 & 66.32 & 60.41 & 53.11 & 65.04 & 58.93 & 51.64 & 60.99 & 56.11 & 44.10 & 60.12 & 51.83 \\
\hline 2015 & 59.11 & 71.09 & 65.00 & 55.36 & 66.40 & 60.72 & 61.22 & 70.60 & 65.84 & 54.71 & 65.87 & 60.17 & 53.12 & 64.82 & 58.83 & 51.63 & 60.90 & 56.06 & 44.74 & 59.79 & 51.99 \\
\hline 2016 & 59.34 & 70.60 & 64.87 & 55.91 & 66.78 & 61.21 & 61.28 & 70.27 & 65.71 & 55.64 & 66.56 & 61.01 & 53.04 & 64.28 & 58.52 & 51.62 & 60.64 & 55.93 & 45.01 & 59.81 & 52.15 \\
\hline 2017 & 59.84 & 70.68 & 65.17 & 55.91 & 66.81 & 61.22 & 61.48 & 70.16 & 65.76 & 55.89 & 66.68 & 61.21 & 52.63 & 63.89 & 58.11 & 51.39 & 60.52 & 55.75 & 44.74 & 59.98 & 52.08 \\
\hline 2018 & 60.49 & 70.96 & 65.63 & 55.91 & 67.11 & 61.37 & 61.30 & 69.64 & 65.41 & 55.95 & 66.79 & 61.28 & 52.42 & 63.72 & 57.92 & 51.63 & 60.34 & 55.79 & 44.32 & 60.03 & 51.89 \\
\hline
\end{tabular}

Selçuk Üniversitesi Sosyal Bilimler Meslek Yüksekokulu Dergisi, Yıl: 2020 Cilt: 23 Sayı:2 
Tablo 2 devam

\begin{tabular}{|c|c|c|c|c|c|c|c|c|c|c|c|c|c|c|c|c|c|c|c|c|c|}
\hline \multirow[b]{2}{*}{ Yillar } & \multicolumn{3}{|c|}{ İrlanda } & \multicolumn{3}{|c|}{ İtalya } & \multicolumn{3}{|c|}{ Japonya } & \multicolumn{3}{|c|}{ Hollanda } & \multicolumn{3}{|c|}{ Norveç } & \multicolumn{3}{|c|}{ Yeni Zelanda } & \multicolumn{3}{|c|}{ A.B.D. } \\
\hline & Kadın & Erkek & Toplam & Kadın & Erkek & Toplam & Kadın & Erkek & Toplam & Kadın & Erkek & Toplam & Kadın & Erkek & Toplam & Kadın & Erkek & Toplam & Kadın & Erkek & Toplam \\
\hline 1995 & 39.93 & 68.39 & 53.94 & 33.56 & 62.27 & 47.29 & 50.00 & 77.60 & 63.40 & 48.30 & 70.40 & 59.20 & 64.54 & 74.30 & 69.42 & 55.81 & 74.14 & 64.73 & 59.05 & 75.05 & 66.72 \\
\hline 1996 & 41.56 & 68.53 & 54.87 & 33.99 & 62.11 & 47.45 & 50.00 & 77.70 & 63.50 & 49.29 & 70.41 & 59.71 & 66.11 & 76.02 & 71.07 & 57.17 & 74.48 & 65.59 & 59.34 & 75.03 & 66.87 \\
\hline 1997 & 42.67 & 68.53 & 55.45 & 34.20 & 61.97 & 47.50 & 50.40 & 77.70 & 63.70 & 50.64 & 71.52 & 60.94 & 67.75 & 77.70 & 72.73 & 57.07 & 74.32 & 65.46 & 59.90 & 75.09 & 67.20 \\
\hline 1998 & 43.93 & 69.40 & 56.45 & 34.68 & 62.01 & 47.78 & 50.10 & 77.30 & 63.30 & 51.47 & 72.19 & 61.69 & 69.18 & 78.55 & 73.86 & 56.97 & 73.57 & 65.03 & 59.85 & 74.89 & 67.09 \\
\hline 1999 & 45.92 & 70.38 & 57.95 & 35.41 & 61.81 & 48.06 & 49.60 & 76.90 & 62.90 & 53.05 & 72.17 & 62.48 & 69.24 & 77.77 & 73.52 & 57.27 & 73.44 & 65.11 & 60.03 & 74.72 & 67.08 \\
\hline 2000 & 47.16 & 71.19 & 58.99 & 35.68 & 61.66 & 48.15 & 49.30 & 76.40 & 62.40 & 54.14 & 73.18 & 63.53 & 69.21 & 78.34 & 73.80 & 57.41 & 73.55 & 65.23 & 59.94 & 74.81 & 67.07 \\
\hline 2001 & 47.57 & 71.14 & 59.19 & 36.22 & 61.40 & 48.31 & 49.20 & 75.70 & 62.00 & 55.10 & 73.51 & 64.18 & 69.50 & 78.17 & 73.85 & 58.27 & 73.81 & 65.79 & 59.79 & 74.44 & 66.82 \\
\hline 2002 & 48.79 & 70.74 & 59.60 & 36.77 & 61.75 & 48.78 & 48.50 & 74.70 & 61.20 & 55.88 & 74.12 & 64.88 & 70.48 & 77.70 & 74.11 & 58.98 & 74.53 & 66.51 & 59.62 & 74.10 & 66.58 \\
\hline 2003 & 49.14 & 70.57 & 59.70 & 37.34 & 62.14 & 49.26 & 48.30 & 74.10 & 60.80 & 56.47 & 73.24 & 64.75 & 69.11 & 76.46 & 72.81 & 59.30 & 73.76 & 66.30 & 59.51 & 73.51 & 66.24 \\
\hline 2004 & 49.43 & 70.99 & 60.07 & 38.45 & 61.90 & 49.68 & 48.30 & 73.40 & 60.40 & 56.93 & 73.08 & 64.90 & 69.09 & 76.00 & 72.56 & 59.78 & 74.49 & 66.90 & 59.16 & 73.33 & 65.99 \\
\hline 2005 & 51.82 & 72.33 & 61.96 & 38.07 & 61.08 & 49.11 & 48.40 & 73.30 & 60.40 & 55.62 & 71.47 & 63.43 & 68.52 & 75.82 & 72.19 & 60.79 & 75.03 & 67.67 & 59.26 & 73.32 & 66.05 \\
\hline 2006 & 53.03 & 73.44 & 63.18 & 38.19 & 60.84 & 49.08 & 48.50 & 73.20 & 60.40 & 56.14 & 71.25 & 63.58 & 68.26 & 75.40 & 71.86 & 61.29 & 75.53 & 68.18 & 59.36 & 73.46 & 66.18 \\
\hline 2007 & 56.98 & 76.40 & 66.63 & 37.94 & 60.44 & 48.75 & 48.50 & 73.10 & 60.40 & 57.40 & 71.91 & 64.54 & 69.39 & 75.83 & 72.64 & 61.69 & 75.54 & 68.39 & 59.31 & 73.22 & 66.04 \\
\hline 2008 & 56.83 & 75.22 & 65.94 & 38.67 & 60.39 & 49.10 & 48.40 & 72.80 & 60.20 & 58.34 & 72.49 & 65.31 & 70.60 & 76.88 & 73.78 & 61.96 & 75.06 & 68.29 & 59.47 & 72.95 & 65.99 \\
\hline 2009 & 56.11 & 72.26 & 64.09 & 38.23 & 59.57 & 48.48 & 48.50 & 72.00 & 59.90 & 58.79 & 72.29 & 65.44 & 69.74 & 75.48 & 72.65 & 61.89 & 74.42 & 67.94 & 59.19 & 71.95 & 65.37 \\
\hline 2010 & 55.25 & 70.18 & 62.60 & 38.17 & 59.08 & 48.21 & 48.50 & 71.60 & 59.60 & 58.70 & 71.16 & 64.84 & 68.64 & 74.87 & 71.80 & 61.64 & 74.14 & 67.67 & 58.62 & 71.18 & 64.71 \\
\hline 2011 & 54.96 & 69.20 & 61.97 & 38.40 & 58.72 & 48.14 & 48.26 & 71.15 & 59.32 & 58.76 & 70.49 & 64.54 & 68.63 & 73.95 & 71.33 & 62.08 & 74.22 & 67.94 & 58.10 & 70.48 & 64.11 \\
\hline 2012 & 54.77 & 68.76 & 61.64 & 39.71 & 59.24 & 49.08 & 48.20 & 70.80 & 59.10 & 59.29 & 70.88 & 65.00 & 68.45 & 74.28 & 71.42 & 62.12 & 73.56 & 67.64 & 57.68 & 70.16 & 63.70 \\
\hline 2013 & 55.27 & 68.90 & 61.96 & 39.68 & 58.65 & 48.79 & 48.90 & 70.50 & 59.30 & 59.24 & 70.81 & 64.95 & 68.33 & 73.73 & 71.08 & 62.51 & 73.51 & 67.81 & 57.21 & 69.73 & 63.25 \\
\hline 2014 & 54.93 & 68.85 & 61.76 & 40.12 & 58.70 & 49.06 & 49.20 & 70.40 & 59.40 & 58.45 & 70.49 & 64.39 & 62.82 & 66.79 & 64.86 & 63.40 & 74.30 & 68.67 & 56.97 & 69.21 & 62.89 \\
\hline 2015 & 54.85 & 69.08 & 61.83 & 39.77 & 58.88 & 48.97 & 49.60 & 70.30 & 59.60 & 58.80 & 70.13 & 64.38 & 62.25 & 67.61 & 64.98 & 63.37 & 74.32 & 68.68 & 56.68 & 69.05 & 62.65 \\
\hline 2016 & 55.59 & 69.03 & 62.18 & 40.45 & 59.25 & 49.50 & 50.30 & 70.40 & 60.00 & 58.68 & 69.65 & 64.09 & 62.06 & 66.87 & 64.52 & 64.52 & 75.33 & 69.79 & 56.80 & 69.19 & 62.79 \\
\hline 2017 & 55.65 & 68.55 & 61.98 & 40.94 & 59.36 & 49.81 & 51.10 & 70.50 & 60.50 & 58.80 & 69.37 & 64.01 & 61.44 & 65.91 & 63.73 & 65.37 & 76.22 & 70.67 & 57.04 & 69.07 & 62.85 \\
\hline 2018 & 56.04 & 68.52 & 62.17 & 41.10 & 59.39 & 49.92 & 52.50 & 71.20 & 61.50 & 59.10 & 69.60 & 64.28 & 61.76 & 66.36 & 64.12 & 65.69 & 76.01 & 70.73 & 57.08 & 69.05 & 62.87 \\
\hline
\end{tabular}

Kaynak:www.ilo.org 


\subsection{Türkiye'de Kadınların İşgücüne Katılım Oranları}

Türkiye hızlı bir sanayileşme hareketi içinde yer almasına karşın tarım ülkesi olma özelliğini de devam ettirmektedir. Bu sebeple kadının işgücüne dâhil olmasında en belirgin özelliklerden birisi istihdama dâhil olan kadın bireylerin büyük bir kısmının tarımsal ve hayvansal üretimin içinde yer almasıdır. Kadın ve erkek eşitsizliğinin sektörel dağılımı ele alındığında kadınların büyük kesiminin yine tarım ve hayvancılık sektöründe ücretsiz aile işçisi olarak istihdam edildiği gayet açık bir şekilde görülmektedir. Kadınların esas işinin, aile ve ev içinde tanımlanmasından dolayı gıda, seramik, tekstil gibi gelir düzeyi düşük ve vasıf gerektirmeyen işlerde yoğun olarak çalışmaktadırlar. Kadınların düşük ücretlerle çalışmasına en büyük neden olan bu iş bölümü aynı zamanda kadını erkeğe bağımlı hale getirmektedir. Bununla beraber, aile içindeki ataerkil yapıyı da devam ettirmektedir (Sayılan, 2012: 24). Bu durumlar kadınların ekonomik bağımsızlığa erişememesine ve istihdama yeterince dâhil olamamaları neden olmaktadır. Kadınların gelir düzeyi düşük ve elastikiyeti yüksek zamanlı işlerde aktif rol oynaması mevcut statülerinin kötüleşmesine de neden olabilmektedir (Ĭğde, 2011: 152). Türkiye'nin Avrupa Birliği'ne uyum kriterlerini sağlamak adına yaptığ düzenlemelerde, kadın ve erkek eşitliği çalışmalarını yasal mevzuata dâhil etme konusuna büyük önem verilmiştir. Bir takım yasal düzenlemeler ile cinsiyete dayalı bütün eşitsizliklerin ortadan derhal kaldırılması hedeflenmiştir. Türk Medeni Kanun'un 2002 yılında yürürlüğe girmesiyle birlikte kadın-erkek eşitsizliğini destekleyen maddeler yürürlükten kaldırılmıştır (Dedeoğlu, 2009: 48).

Tablo 3' te Türkiye'de yıllar itibariyle toplam işgücü, kadın ve erkek işgücü istihdam oranları verilmiştir. Verilere göre, 1990 ve 2008 yılları arasında düşüş olduğu ancak 2008'den sonra da tekrar bir artış olduğu gözlenmektedir.

Tablo 3. Türkiye'de 15 Yaş Üstü Toplam İstihdam Oranı ve Bu Oranı İçindeki Kadın ve Erkek İstihdam Oranları (\%)

\begin{tabular}{|l|lll|}
\hline Ylllar & Kadın & Erkek & Toplam \\
\hline $\mathbf{1 9 9 0}$ & 34.1 & 79.7 & 56.6 \\
$\mathbf{1 9 9 1}$ & 34.1 & 80.2 & 57.0 \\
$\mathbf{1 9 9 2}$ & 32.7 & 79.6 & 56.0 \\
$\mathbf{1 9 9 3}$ & 26.8 & 78.0 & 52.1 \\
$\mathbf{1 9 9 4}$ & 31.3 & 78.5 & 54.6 \\
$\mathbf{1 9 9 5}$ & 30.9 & 77.8 & 54.1 \\
$\mathbf{1 9 9 6}$ & 30.6 & 77.3 & 53.7 \\
$\mathbf{1 9 9 7}$ & 28.8 & 76.7 & 52.6 \\
$\mathbf{1 9 9 8}$ & 29.3 & 76.7 & 52.8 \\
$\mathbf{1 9 9 9}$ & 30.0 & 75.8 & 52.8 \\
$\mathbf{2 0 0 0}$ & 26.6 & 73.7 & 49.9 \\
$\mathbf{2 0 0 1}$ & 27.1 & 72.9 & 49.8 \\
$\mathbf{2 0 0 2}$ & 27.9 & 71.6 & 49.6 \\
$\mathbf{2 0 0 3}$ & 26.6 & 70.4 & 48.3 \\
$\mathbf{2 0 0 4}$ & 23.3 & 70.3 & 46.3 \\
$\mathbf{2 0 0 5}$ & 23.3 & 70.6 & 46.4 \\
$\mathbf{2 0 0 6}$ & 23.6 & 69.9 & 46.3 \\
$\mathbf{2 0 0 7}$ & 23.6 & 69.8 & 46.2 \\
$\mathbf{2 0 0 8}$ & 24.5 & 70.1 & 46.9 \\
$\mathbf{2 0 0 9}$ & 26.0 & 70.5 & 47.9 \\
$\mathbf{2 0 1 0}$ & 27.6 & 70.8 & 48.8 \\
$\mathbf{2 0 1 1}$ & 28.8 & 71.7 & 49.9 \\
$\mathbf{2 0 1 2}$ & 29.5 & 71.0 & 50.0 \\
$\mathbf{2 0 1 3}$ & 30.8 & 71.5 & 50.8 \\
$\mathbf{2 0 1 4}$ & 30.3 & 71.3 & 50.5 \\
$\mathbf{2 0 1 5}$ & 31.5 & 71.6 & 51.1 \\
$\mathbf{2 0 1 6}$ & 32.5 & 72.0 & 51.8 \\
$\mathbf{2 0 1 7}$ & 33.6 & 72.5 & 52.6 \\
$\mathbf{2 0 1 8}$ & 34.2 & 72.7 & 52.9 \\
\hline Kaynak: www.ilo.org & & \\
& & & \\
\hline
\end{tabular}




\section{LITERATÜR TARAMASI}

Mammen ve Paxson (2000)'un yaptığı çalışma, kadının işgücüne katılımının ekonomik kalkınmaya olan etkileri ile ilgilidir. 1970-1980 yılları arasını kapsayan ve 90 ülkeyi içeren bu çalışma, ekonomik büyümede kadının rolünü, eğitim seviyesini, istihdama katılım oranını, ücretlerini ve doğurganlık faktörü yardımıyla açıklamıştır. Gelişmekte olan ülkelerde kadının toplumdaki statüsünü, daha düşük eğitimli olması ve aile içi işleri de gerçekleştirmesi kadının işgücüne katılımını büyük oranda etkilediğini ifade etmişlerdir.

Tansel (2002)'nin yaptığı çalışmada, ülke ekonomisine katkısı için, kadın istihdamının ekonomik büyümedeki etkisi il bazlı olarak araştırılmıştır. 67 ilde gerçekleştirilen ve üç ayrı dönemi kapsayan analizler sonucunda ekonomik büyüme ile kadının işgücüne katılımı arasında U-şekilli bir bağ saptanmıştır. Bu demek oluyor ki, belli bir noktaya dek kadının işgücüne katılımı arttıkça ekonomik büyüme negatif yönde etkilenmektedir. Ancak sonraki süreçte bu negatiflik giderilmekte ve katılım oranı ekonomik büyümeyi pozitif yönde etkilemektedir. Bunun dışında eğitim faktörünün kadın işgücüne katılımın oranında olumlu bir etkisi varken, işsizlik faktörünün de bu oran üzerinde güçlü bir olumsuz etkisi bulunmaktadır.

Lee ve ark. (2008)'in yaptığ çalışmada bir ülkenin ekonomik büyümesinde kadın işgücünün katılım oranlarının etkisi araştırılmışıtır. Kadınların işgücüne dâhil olmalarını etkileyen unsurlardan "evlilik" unsurunu araştıran bu çalışma, evli kadınların evli olmayanlara kıyasla daha düşük oranda işgücüne katıldıkları saptamış ve bu durumun ekonomik büyüme açısından negatif bir faktör olduğundan bahsetmiştir.

Bloom ve ark. (2009)'nın gerçekleştirdiği bir çalışma, kadınların işgücüne katılım oranının belirleyicilerini ve bu belirleyicilerle ekonomik büyüme arasındaki bağlantıyı araştırmaktadır. Çalışmada 97 ülkenin 19602000 seneleri arasında kadınların işgücüne katılma miktarını etkileyen faktörler belirlenmiştir. Bu faktörler, kürtaj, eğitim düzeyi, doğurganlık oranı, kişi başına gelir düzeyi ve nüfustur. Bu çalışmada varılan sonuçlara göre eğitim seviyesi ve doğurganlık faktörü arasında bir ilişki olmadığı saptanmıştır. Bunun dışında eğitim seviyesi ile kadınların işgücüne katılım oranı arasında olumlu yönde bir bağıntı olduğu saptanmıştır. Çalışma sonuçlarına göre "kadınların işgücüne katılım oranları ile ekonomik büyüme arasında doğru orantılı bir bağ olduğu" ortaya çıkmıştır.

Lahoti ve Swaminathan (2013) tarafından Hindistan ekonomisi için 1983-2010 yılları arasını kapsayan bir çalışma gerçekleştirmiş ve pek çok çalışmada olduğu gibi "kadın işgücüne katılım oranlarıyla ülkenin ekonomik büyümesi arasında U şekilli bir bağın Hindistan ekonomisi için çelişkili bir durum” olduğunu ortaya koymuştur. Bu çalışmada ulaşılan sonuçlarda 25-29 yaş arasındaki kadınların işgücüne katılımlarının o dönemde \%23 düşüş yaşadığını ve bunun çoğunlukla fakir olan bölgelerde daha fazla olduğu yönündedir. Özet olarak Hindistan ekonomisinin devamlı olarak büyüdüğü hipoteziyle, ekonomik büyüme ve kadının işgücüne katılımı arasında ters yönlü bir ilişki saptanmıştır.

Tsani ve ark. (2013)'nın 11 ülke ile gerçekleştirdiği çalışma, kadınların işgücüne katılımlarıyla ekonomik büyüme arasındaki bağıntıyı iki kademeli tahmin yaklaşımıyla araştırmaktadır. Gerçekleştirilen çalışma sonuçlarına göre, U şekilli bir bağ saptanmıştır. Kadının işgücüne katılımlarındaki birtakım engellerin ortadan kaldırılmasının ve eğitim açısından düşük düzeyde olan kadınların işgücüne katılımın artmasının ekonomik büyüme üzerinde pozitif etkilere sebep olabileceği vurgulanmıştır.

Besamusca ve ark. (2016)'nın 117 ülke ile 1990-2010 seneleri arasında gerçekleştirdiği çalışmada ülkenin ekonomik büyümesine etkisi olduğu düşünülen kadının işgücüne katılımını etkileyen bazı faktörleri saptayıp ekonomik büyümedeki tesirini açığa çıkarmaya yöneliktir. Bahsi geçen bu çalışmada eğitim seviyesi, kadınların medeni durumu ve annelik faktörlerinin kadınların işgücüne katılımları üzerinde tesiri olduğunu ve bu faktörlerin etkisinin ekonomik büyümeyi pozitif ya da negatif yönde etkileyebileceğinin altı çizilmektedir.

\section{VERI VE METODOLOJI}

Ekonometrik çerçeve; kadın istihdamı ve ekonomik büyüme arasındaki uzun dönemli ilişkisine bakarken, aynı zamanda ekonomik büyümenin sürükleyici kuvvetleri olan sermaye stoğu ve toplam işgücü değişkenlerini de analizde kullanacaktır. Ekonometrik analizlerin bulgularını sunarken, önceki ampirik çalışmalar da bu bulguların sonuçları ile karşılaştırılacaktır.

\subsection{Ekonometrik Model}

Bu çalışmada gayri safi yurtiçi hasıla, kadın istihdam oranı, toplam işgücü miktarı ve sermaye stoğu serileri kullanılmıştır. Tüm verilerin logaritmik ölçekleri alınmıştır. Doğrusal bir ilişkiye bakıldığ 1 için serilerin logaritmasının alınması anlamlı olacak ve seride herhangi bir olağandışı sapma varsa regresyonun daha doğru tahmin etmesini sağlayacaktır. Analizde kullanılan değişkenlerin zaman boyutu 2003 ve 2017 yıllarını kapsamaktadır. Veriler çeyrek dönemler itibariyle düzenmiş ve bu zaman dilimindeki gözlem sayıları böylece

Selçuk Üniversitesi Sosyal Bilimler Meslek Yüksekokulu Dergisi, Yıl: 2020 Cilt: 23 Sayı:2 
artırılmıştır. Gerek gayri safi yurtiçi hasıla gerekse de işgücü ile ilgili seriler mevsimsel özellikler gösterdiği için serilermevsimsel etkilerden arındırılmıştır.

Kadın istihdamı ve ekonomik büyüme arasındaki uzun vadeli ilişkiyi incelemek ve değişkenler arasında uzun dönemli bir ilişki olup olmadığını görmek için eşbütünleşme modelleri uygulanacaktır. Bu çalışmada, değişkenler arasındaki ilişkiyi bulmak için Pesaran vd. (2001) ARDL eşbütünleşme testi (Autoregressive Distributed Lags) yöntemi uygulanıp, değişkenler arasında eşbütünleşmenin bulunması halinde ise ARDL tahmin modeli ile kısa ve uzun dönemli ilişkiye bakılacaktır. ARDL yönteminin diğer yöntemlerden farkı ise değişkenlerin durağanlık seviyesine bakılmaksızın bir zaman serisi analizi gerçekleştirmesidir. Çalışmada ekonomik büyümeyi göstermek için gayri safi yurtiçi milli hasıla serisi bağımlı değişken, diğer seriler, yani kadın istihdamı, sermaye stoğu ve toplam işgücü ise bağımsız değişkenler olarak yer alacaktır. Bağımlı ve bağımsız değişkenleri alarak aşağıdaki doğrusal tahmin ilişkisi incelenecektir:

$$
\ln G S Y H=\beta_{0}+\beta_{1} \ln K I+\beta_{2} \ln I S+\beta_{3} \ln S E R
$$

1 nolu tahmin denkleminde GSYH, gayri safi yurt içi hasıla verisini; KI, kadın istihdamını; IS, toplam işgücünü ve SER ise yatırımları gösteren sermaye stoğunu temsil etmektedir.

Değişkenin istatistiksel değerlendirmesini görmeye devam etmeden önce, değişkenlerin durağan olup olmadığını kontrol etmek gerekir. Örneğin, zaman serileri için, Sarı vd (2007), zaman serisinin karakteristik özelliklerini öğrenmek ve modele uyacak sağlam birim kök tahmin edicilerinin uygulanarak belirlenebileceğini önermektedir. Zaman serilerindeki değişkenleri analizinde sahte regresyonu önlemek için bu seriler durağan olmalıdır. Başka bir deyişle, t, F ve R2'nin geleneksel değerleri durağan olmayan serilerde farklı sonuçlar üretebilir. Örneğin, regresyon sonuçları yüksek bir değere sahip olmasına rağmen aslında aralarında hiçbir ilişki olmayabilir. Bu durum sahte regresyona yol açmakta ve yorumlamalarda hatalara neden olmaktadır (Brooks, 2004). Durağan değişkenlerle, sahte regresyon olasılığı ortadan kalkacak ve aynı zamanda regresyonun önemi de artacaktır (MacKinnon, 1991).

$\mathrm{Bu}$ çalışmada kullanılacak olan verilerin durağanlık özelliklerini öğrenebilmek için literatürde sıkça kullanılan bazı birim kök testleri kullanılacak ve sonuçlarına göre tahmin en uygun regresyon tahminleri ile değişkenler arasındaki ilişki bulunacaktır.

Kullanılacak olan birim kök testleri sırasıyla (ADF) Augmented Dickey-Fuller testi (1979); (PP) Philip ve Perron testi (1988); (ERS)Elliott, Rothenberg, andStock Point Optimal testi (1996) ve (KPSS) Kwiatkowski, Phillips, Schmidt, andShin (1992) testleridir. Bu testler Eviews programı kullanılarak yapılmış ve sonuçları Tablo 8' de sunulmuştur.

Tablo 4: Birim kök test sonuçları, değişkenler seviyelerindeyken.

\begin{tabular}{|c|c|c|c|c|c|}
\hline \multirow[t]{2}{*}{ Değisşkenler } & \multirow[t]{2}{*}{ Test } & \multicolumn{2}{|c|}{ Sabit } & \multicolumn{2}{|c|}{ Sabit ve Trend } \\
\hline & & Ístatistik & p-dě̆eri & Istatistik & $p$-değeri \\
\hline \multirow[t]{4}{*}{ Ingsyih } & $\mathrm{ADF}$ & -0.5821 & 0.8662 & -2.3356 & 0.4087 \\
\hline & PP & -0.5682 & 0.8693 & -2.3382 & 0.4073 \\
\hline & ERS & 262.430 & & 12.4100 & \\
\hline & KPSS & $0.9517 * * *$ & & 0.10311 & \\
\hline \multirow[t]{4}{*}{ Inkadın } & $\mathrm{ADF}$ & -0.7584 & 0.8222 & -3.4042 & 0.0617 \\
\hline & $\mathrm{PP}$ & -0.8276 & 0.8037 & -5.0948 & 0.0005 \\
\hline & ERS & 9.8874 & & 41.922 & \\
\hline & KPSS & $0.7643 * * *$ & & $0.1797 * *$ & \\
\hline \multirow[t]{4}{*}{ Lnis } & ADF & 0.7068 & 0.9913 & -2.6217 & 0.2727 \\
\hline & $\mathrm{PP}$ & 1.5488 & 0.9993 & -3.0012 & 0.1406 \\
\hline & ERS & 104.70 & & 47.8500 & \\
\hline & KPSS & $0.8988 * * *$ & & $0.89880 * * *$ & \\
\hline \multirow[t]{4}{*}{ Lnser } & $\mathrm{ADF}$ & -1.5551 & 0.4988 & -2.9394 & 0.1559 \\
\hline & PP & -1.7885 & 0.3826 & -2.7363 & 0.2190 \\
\hline & ERS & 152.650 & & $4.0905^{* * *}$ & \\
\hline & KPSS & $0.9421 * * *$ & & 0.0762 & \\
\hline
\end{tabular}


Tablo 5: Birim kök test sonuçları, değişkenler birinci dereceden fark alınmışken

\begin{tabular}{|c|c|c|c|c|c|}
\hline \multirow[t]{2}{*}{ Değişkenler } & \multirow[t]{2}{*}{ Test } & \multicolumn{2}{|c|}{ Sabit } & \multicolumn{2}{|c|}{ Sabit ve Trend } \\
\hline & & Istatistik & $p$-dĕgeri & Istatistik & $p$-dĕgeri \\
\hline \multirow[t]{4}{*}{ lngsyih } & $\mathrm{ADF}$ & -8.233 & 0.0000 & -8.156 & 0.0000 \\
\hline & $\mathrm{PP}$ & -8.233 & 0.0000 & -8.156 & 0.0000 \\
\hline & ERS & $0.932 * * *$ & & $3.281 * * *$ & \\
\hline & KPSS & 0.083 & & 0.084 & \\
\hline \multirow[t]{4}{*}{ Lnkı } & $\mathrm{ADF}$ & -2.049 & 0.2656 & -1.875 & 0.6531 \\
\hline & $\mathrm{PP}$ & -8.062 & 0.0000 & -8.575 & 0.0000 \\
\hline & ERS & 99.324 & & 147.010 & \\
\hline & KPSS & 0.500 & & 0.143 & \\
\hline \multirow[t]{4}{*}{ Lnis } & $\mathrm{ADF}$ & -3.437 & 0.0137 & -3.811 & 0.0233 \\
\hline & $\mathrm{PP}$ & -7.596 & 0.0000 & -12.306 & 0.0000 \\
\hline & ERS & $1.861 * * *$ & & $3.227 * * *$ & \\
\hline & KPSS & 0.316 & & $0.320 * * *$ & \\
\hline \multirow[t]{4}{*}{ Lnser } & $\mathrm{ADF}$ & -3.918 & 0.0035 & -3.973 & 0.0150 \\
\hline & $\mathrm{PP}$ & -4.048 & 0.0024 & -4.129 & 0.0099 \\
\hline & ERS & $1.312 * * *$ & & $4.422 * * *$ & \\
\hline & KPSS & 0.168 & & 0.084 & \\
\hline
\end{tabular}

$*, * *, * * *$ işaretleri sırasıyla $\% 10, \% 5$ ve $\% 1$ anlamllılı derecelerini göstermektedir.

Birim kök test sonuçları değişkenleri hem seviyelerinde hem de birinci dereceden farkları alınarak hesaplanmıştır. Tablo $8^{\prime}$ de görüldüğ̈̈ üzere hemen hemen tüm seriler seviyelerinde durağan görünmemektedir. Sadece kadın istihdamı serisinde test sonuçları karmaşık sonuç vermiştir. Örneğin, ADF, PP ve ERS testleri seviyede durağan gösterirken KPSS testi ise durağan olmadığını göstermiştir. Yalnız kadın istihdam serisine trend eklendiğinde bu verinin durağan olmadığı testlerin büyük kısmında tespit edilmiştir. $\mathrm{O}$ yüzden kadın istihdam serisinde I(0) ve I(1) bütünleşik sıralama olabilir. Diğer tarafta Tablo 2'de görüldüğü gibi serilerin birinci dereceden farkları alındığında tüm test istatistikleri kullanılan değişkenlerin durağan olduğunu bulmuştur.

Yukarıda belirtildiği gibi farklı dereceden bütünleşik serilerin regresyon analizinde kullanılmasına olanak sağlayan ARDL yöntemi bu çalışmanın analizinde kullanılacak en uygun ekonometrik modelleme olacağını birim kök test sonuçları göstermektedir.

Değişkenler arasında uzun dönemli ilişkiye bakmak için öncelikle ARDL testinin önerdiği kısıtsız hata düzeltme modeli (Error CorrectionTerm) kullanılacaktır. Kısıtsız hata düzeltme modeli serilerin eşbütünleşme içinde olup olmadıklarını gösterir ve serilerin kısa ve uzun dönemdeki dinamikleri ile ilgili bilgi vermektedir.

Uzun ve kısa dönemli ARDL denklemi şu şekilde olacaktır.

$$
\begin{aligned}
\Delta \operatorname{lnGSYH}_{\mathrm{t}}= & \mathrm{a}_{0}+\sum_{\mathrm{i}=1}^{\mathrm{n}} \beta_{1 \mathrm{t}} \Delta \operatorname{lnGSYH}_{\mathrm{t}-\mathrm{i}}+\sum_{\mathrm{i}=0}^{\mathrm{n}} \beta_{2 \mathrm{t}} \Delta \operatorname{lnKI}_{\mathrm{t}-\mathrm{i}}+\sum_{\mathrm{i}=0}^{\mathrm{n}} \beta_{3 \mathrm{t}} \Delta \operatorname{lnIS} \mathrm{S}_{\mathrm{t}-\mathrm{i}}+\sum_{\mathrm{i}=0}^{\mathrm{n}} \beta_{4 \mathrm{t}} \Delta \operatorname{lnSER}_{\mathrm{t}-\mathrm{i}} \\
& +\gamma_{1} \operatorname{LnGSYH}_{\mathrm{t}-1}+\gamma_{2} \operatorname{lnKI}_{\mathrm{t}-1}+\gamma_{3} \operatorname{lnIS}_{\mathrm{t}-1}+\gamma_{4} \operatorname{lnSER}_{\mathrm{t}-1}+\varepsilon_{\mathrm{t}}
\end{aligned}
$$

2 numaralı eşitlikte a, sabit terimi ve $\Delta$, birinci derecen fark işlemcisini ifade etmektedir. Yine 1 numaralı eşitlikte olduğu gibi lnGSYH, gayri safi yurt içi hasıla verisini; lnKI, kadın istihdamını; lnIS, toplam işgücünü ve $\ln$ SER ise yatırımları gösteren sermaye stoğunu temsil etmektedir. $\varepsilon_{\mathrm{t}}$ ise hata terimini göstermektedir.

ARDL sınır testini (ARDL Bound Test) uzun dönemli ilişkiyi ortaya çıkartmak için F-istatistiğini kullanmakta ve bu F-istatistiği değişkenlerin eşbütünleşik durumlarına göre, yani $\mathrm{I}(0)$ veya $\mathrm{I}(1)$ alt ve üst değerler belirlemiştir. F-istatistiğine ilişkin olarak yer alan hipotezlerin reddi ya da kabulü bu değerlere göre verilmektedir. Eğer bulunan F-istatistiği bu değerlerin altında olursa eşbütünleşme yoktur hipotezi kabul edilecektir. Yine, bulunan F-istatistiği üst sınırın üstünde çıkarsa da eşbütünleşme vardır hipotezi kabul edilecek ve değişkenler arasında uzun dönem ilişkisi varsayımı kabul edilecektir. Bir diğer önemli nokta ise, eğer hesaplanan F-istatistiği her iki sınırın arasında bulunursa da, eşbütünleşme hakkında herhangi bir çıkarım yapilamayacaktır. 
$\mathrm{H}_{0}: \gamma_{1}=\gamma_{2}=\gamma_{3}=\gamma_{4}=0$ (Değişkenler arasında eşbütünleşme yoktur)

$\mathrm{H}_{1}: \gamma_{1} \neq \gamma_{2} \neq \gamma_{3} \neq \gamma_{4} \neq 0$ (Değişkenler arasında eşbütünleşme vardır)

Yukarıda sınır testi ile ilgili hipotezler belirtildikten sonra uzun dönemli denklemimizi oluşturmak ve ARDL modelindeki katsayılarını ve hata düzeltme modelini tahmin etmek için aşağıdaki eşitlikler kullanılacaktır.

ARDL modeli şu şekilde olacaktır:

$$
\operatorname{lnGSYH}=\mathrm{a}_{0}+\sum_{\mathrm{i}=1}^{\mathrm{m}} \mathrm{a}_{1 \mathrm{i}} \operatorname{lnGSYH}_{\mathrm{t}-\mathrm{i}}+\sum_{\mathrm{i}=0}^{\mathrm{n}} \mathrm{a}_{2 \mathrm{i}} \ln \mathrm{KI}_{\mathrm{t}-\mathrm{i}}+\sum_{\mathrm{i}=0}^{\mathrm{p}} \mathrm{a}_{3 \mathrm{i}} \operatorname{lnIS}_{\mathrm{t}-\mathrm{i}}+\sum_{\mathrm{i}=0}^{\mathrm{r}} \mathrm{a}_{4 \mathrm{i}} \operatorname{lnSER}_{\mathrm{t}-\mathrm{i}}+\varepsilon_{\mathrm{i}}
$$

Hata düzeltme modeli (ECT) ise şu şekildedir;

$$
\begin{aligned}
\Delta \operatorname{lnGSYH}= & \mathrm{a}_{0}+\sum_{\mathrm{i}=1}^{\mathrm{m}} \lambda_{1 \mathrm{i}} \Delta \operatorname{lnGSYH}_{\mathrm{t}-\mathrm{i}}+\sum_{\mathrm{i}=0}^{\mathrm{n}} \lambda_{2 \mathrm{i}} \Delta \ln \mathrm{II}_{\mathrm{t}-\mathrm{i}}+\sum_{\mathrm{i}=0}^{\mathrm{p}} \lambda_{3 \mathrm{i}} \Delta \operatorname{lnIS}_{\mathrm{t}-\mathrm{i}}+\sum_{\mathrm{i}=0}^{\mathrm{r}} \lambda_{4 \mathrm{i}} \Delta \operatorname{lnSER} \mathrm{L}_{\mathrm{t}-\mathrm{i}} \\
& +\lambda_{5} \mathrm{ECT}_{\mathrm{t}-1}+\varepsilon_{\mathrm{i}}
\end{aligned}
$$

Eşitlik 4'te kullanılan ECT (Error Correction Term) katsayısının anlamı ise kısa dönemde oluşabilecek dengesiz pozisyonların tekrar uzun dönem ilişkileri seviyesine getiren bir mekanizmadır.

\subsection{Sınır Testi Sonuçları}

GSYİH değişkenin bağımlı ve diğer (Kadın İstihdamı, Toplam İşgücü ve Sermaye Stoğu) değişkenlerin bağımsız olduğu eşitliğin sınır testi sonuçları aşağıda yer almaktadır. Tahmin edilen ARDL modeli şöyledir: $\operatorname{ARDL}(4,4,1,1)$

Tablo 6: Sınır testi sonuçları

\begin{tabular}{|lll|}
\hline \multicolumn{3}{|l|}{ F-istatistik değeri: 6.9426} \\
\hline \multicolumn{2}{|l|}{ Sinır testi değerleri } \\
\hline \multicolumn{2}{|l|}{ Anlamlılık $\quad \mathrm{I}(0)$ sinırı } & $\mathrm{I}(1)$ sınırı \\
\hline $10 \%$ & 2.72 & 3.77 \\
\hline $5 \%$ & 3.23 & 4.35 \\
\hline $2.5 \%$ & 3.69 & 4.89 \\
\hline $1 \%$ & 4.29 & 5.61 \\
\hline
\end{tabular}

Tablo 10'da görüldüğü üzere sınır testinden elde edilen F-istatistiği gayri safi yurt içi hasıla ile kadın istihdamı, toplam işgücü ve sermaye stoğu arasında uzun dönemli bir ilişki yani değişkenler arasında eşbütünleşme olduğunu tespit etmiştir. Bulunmuş olan F-istatistiği belirtilen I(1) üst sınırının üstünde yer almış ve eşbütünleșme yoktur hipotezi reddedilmiștir.

Eşbütünleşmenin varlığ 1 için kullanılan denklemde değişkenler arasında otokorelasyon ve oluşturulan denklem sisteminin istikrarlı yani stabil olup olmadığı ise diagnostik testlere bakılmıştır.

\section{Tablo 7: Otokorelasyon ve Sabit Varyans Test Sonuçları}

\begin{tabular}{|l|l|l|l|l|}
\hline Breusch-GodfreyOtokorelasyon LM Test: & F-istatistik & 0.591036 & Prob. F(2,40) & 0.5585 \\
\hline $\begin{array}{l}\text { Heteroskedasticity Test: Breusch-Pagan- } \\
\text { Godfrey (Sabit Varyans Testi) }\end{array}$ & F-istatistik & 1.015077 & Prob. F(13,42) & 0.4552 \\
\hline
\end{tabular}

Tablo11'de p değerlerine bakıldığında, otokorelasyon ve sabit varyans yoktur hipotezleri kabul edilir ve sistemin otokorelasyon ve değişen varyans içermediği görülebilir. 
Analizde kullanılan değişkenler arasında eşbütünleşmenin bulunması nedeniyle ECT kullanılarak, yani ARDL hata düzeltme modeli, uzun ve kısa dönemde değişkenler arasındaki etkileşim tahmin edilebilir. Hata düzeltme modeli ve değişkenlerin uzun dönem katsayıları Tablo 12’ de derlenmiştir.

Tablo 8: Hata Düzeltme Modeli (ECT) Sonuçları (Sadece sabit)

\begin{tabular}{|l|l|l|l|l|}
\hline Değişkenler & Katsayılar & Std. Hata & t-istatistiği & Prob. değeri \\
\hline $\mathrm{D}(\mathrm{LNGS}(-1))$ & -0.216797 & 0.139414 & -1.555065 & 0.1273 \\
\hline $\mathrm{D}(\mathrm{LNGS}(-2))$ & -0.243014 & 0.126188 & -1.925807 & 0.0608 \\
\hline $\mathrm{D}(\mathrm{LNGS}(-3))$ & -0.293684 & 0.108067 & -2.717619 & 0.0094 \\
\hline $\mathrm{D}(\mathrm{LNKI})$ & 0.512756 & 0.220161 & 2.329005 & 0.0246 \\
\hline $\mathrm{D}(\mathrm{LNKI}(-1))$ & -0.147075 & 0.190753 & -0.771023 & 0.4449 \\
\hline $\mathrm{D}($ LNKI(-2)) & -0.239336 & 0.121045 & -1.977239 & 0.0544 \\
\hline $\mathrm{D}(\mathrm{LNIS})$ & -0.903766 & 0.304185 & -2.971107 & 0.0048 \\
\hline $\mathrm{D}(\mathrm{LNSER})$ & 0.542011 & 0.080980 & 6.693106 & 0.0000 \\
\hline CointEq(-1) & -0.574739 & 0.146055 & -3.935088 & 0.0003 \\
\hline
\end{tabular}

Tablo 9: ARDL Uzun Dönem Tahmin Katsayıları (Sadece sabit)

\begin{tabular}{|l|l|l|l|l|}
\hline Değişkenler & Katsayılar & Std. Hata & t-istatistiği & Prob. değeri \\
\hline LNKI & -0.216797 & 0.139414 & -1.555065 & 0.1273 \\
\hline LNİS & -0.243014 & 0.126188 & -1.925807 & 0.0608 \\
\hline LNSER & -0.293684 & 0.108067 & -2.717619 & 0.0094 \\
\hline C & 0.512756 & 0.220161 & 2.329005 & 0.0246 \\
\hline
\end{tabular}

Veri setinin tüm değişkenlerinde trend ile karşılaşıldığ 1 için hata düzeltme modelinin eşitliğine trend faktörününde eklenmesi gerekir. Bu yüzden yukarıdaki hata düzeltme modelinde sabit katsayısına ek olarak trend değişkeni de eklendiğinde modelin katsayıları kısa dönemli ve uzun dönemli olarak aşağıdaki Tablo 14 ve Tablo 15 'te verilmiştir.

Tablo 10: Hata Düzeltme Modeli (ECT) Sonuçları (Sadece sabit ve trend)

\begin{tabular}{|l|l|l|l|l|}
\hline Değişkenler & Katsayılar & Std. Hata & t-istatistiği & Prob. değeri \\
\hline $\mathrm{D}($ LNGS(-1)) & -0.148236 & 0.181153 & -0.81829 & 0.4182 \\
\hline $\mathrm{D}($ LNGS(-2)) & -0.214215 & 0.158645 & -1.350277 & 0.1847 \\
\hline $\mathrm{D}($ LNGS(-3)) & -0.289907 & 0.125627 & -2.30769 & 0.0264 \\
\hline $\mathrm{D}($ LNKI) & 0.536157 & 0.230727 & 2.32377 & 0.0254 \\
\hline $\mathrm{D}($ LNISS) & -0.549379 & 0.317138 & -1.732303 & 0.0911 \\
\hline $\mathrm{D}($ LNISS(-1)) & -0.44026 & 0.262664 & -1.676135 & 0.1017 \\
\hline $\mathrm{D}($ LNIS(-2)) & -0.482335 & 0.185259 & -2.603574 & 0.013 \\
\hline $\mathrm{D}($ LNSER) & 0.609996 & 0.091122 & 6.694258 & 0.0000 \\
\hline $\mathrm{D}($ LNSER(-1)) & 0.15432 & 0.127111 & 1.214065 & 0.232 \\
\hline $\mathrm{D}($ LNSER(-2)) & 0.089163 & 0.12157 & 0.733434 & 0.4677 \\
\hline $\mathrm{D}($ LNSER(-3)) & -0.191082 & 0.087032 & -2.195524 & 0.0341 \\
\hline $\mathrm{D}($ TREND) & -0.005271 & 0.001617 & -3.259975 & 0.0023 \\
\hline CointEq(-1) & -0.889645 & 0.20974 & -4.241658 & 0.0001 \\
\hline
\end{tabular}


Tablo 11: ARDL Uzun Dönem Tahmin Katsayıları (Sadece sabit ve trend)

\begin{tabular}{|l|l|l|l|l|}
\hline Değişkenler & Katsayılar & Std. Hata & t-istatistiği & Prob. değeri \\
\hline & & & & \\
\hline LNKI & -0.403607 & 0.164881 & -2.447869 & 0.0190 \\
\hline LNIS & 1.242781 & 0.252634 & 4.919296 & 0.0000 \\
\hline LNSER & 0.561406 & 0.042744 & 13.134254 & 0.0000 \\
\hline C & 1.165778 & 2.298517 & 0.507187 & 0.6149 \\
\hline
\end{tabular}

Hata düzeltme modelleri hem sabit hem trend eklendiğinde kısa dönemde kadın istihdam oranının ilk seviyesinde ekonomik büyüme ile pozitif ilişki içinde olduğunu istatiksel olarak anlamlı bir şekilde ifade etmektedir. Yine sonuçlara göre, sadece sabit varken, kısa dönemde kadın istihdamının iki gecikmeli değeri de anlamlı çıkmakta ama bu durumda negatif bir ilişki ortaya çıkmaktadır. Ancak hata düzeltme modelinin ikinci modelinde verilerin trend içermesi nedeniyle, trend değişkeni eklendiğinde kadın istihdamı ile ekonomik büyüme arasında pozitif ilişkinin varlığı ortaya çıkmaktadır. Uzun dönem katsayılarına bakıldığın da ise yine kadın istihdam ile ekonomik büyüme arasında anlamlı bir ilişki çıkmakta ancak sürpriz bir şekilde bu ilişkinin yönü negatif görülmektedir. Bu durumun ortaya çıkması gayet normal olarak görülebilir, çünkü ekonominin büyüme dönemleri bir döngü içinde ve ekonomik gelişmeleri etkileyen işgücü gibi bazı faktörler ise uzun dönemde bu döngüden farklı bir seyir izleyebilir. Ülkelerin ekonomik gelişmeleri, Türkiye dahil işgücünden bağımsız olarak günümüzde bir çok faktörden etkilenebilir. Örneğin teknolojide yaşanan olağanüstü adımlar daha fazla istihdam olmadan büyüme tarafında verimliliği yükseltmiştir ki bu durum toplam işgücü miktarının katsayılarında da kendisini göstermektedir. Her ne kadar uzun dönemde işgücü ile ekonomik büyüme arasında negatif bir ilişki bulunmuşsa da kısa dönemde ekonomik teorilere uygun olarak pozitif ilişkinin varlı̆̆ test sonuçları tarafından ortaya çıkarılmıştır. Öte yandan ekonomik büyüme ile sermaye stoğu arasında hem kısa dönemde hem uzun dönemde pozitif bir ilişkinin bulunması kullanılan kaynakların aslında verimlilik artışına sebep olduğunu ve verimlilik artışının da ekonomik büyümeye yol açtığı rahatlıkla söylenebilir. Genel olarak bu çalışmanın sonuçları kısmen literatürün Türkiye örneğinde yapılan çalışmalar, örneğin Günsoy ve Özsoy (2012), Serel ve Özdemir (2017), Zeren ve Savrul (2017) ve Pata (2018) bulunan kadın istihdamı ile ekonomik büyüme arasındaki pozitif ilişkiye paralellik göstermiştir.

\subsection{Nedensellik Analizi}

Analiz kısmının son aşamasında ise calışmada kullanılan değişkenlerin birbirlerini etkileyip etkilemedikleri nedensellik testi kullanılarak araştırılacaktır. Bu nedenle çalışmalarda sıkça kullanılan Granger Causality Testi çalışmanın bu kısmında benimsenmiştir. Granger nedensellik testi değişkenlerin durağan olması yani birim kök içermemesi halinde geçerli olmakta ve doğru tahmin yapmaktadır. Birim kök testi sonuçları da, çalışmada kullanılan değişkenlerin seviyelerinde durağan olmadığı ve birinci dereceden farkları alındığında durağanlaştı̆̆ını göstermiştir. Bu nedenle kullanılan seriler farkları alınıp teste tabi tutulacaktır.

Tablo 12: Granger Nedensellik Test Sonuçları

\begin{tabular}{lll}
\hline Null Hipotezi: & F-İstatistiği & P-değeri \\
\hline LNKI, LNGS Granger nedeni değildir & 1.87295 & 0.1309 \\
LNGS, LNKIGranger nedeni değildir & 2.43498 & 0.0602 \\
LNIS, LNGS Granger nedeni değildir & 1.92703 & 0.1215 \\
LNGS, LNIS Granger nedeni değildir & 1.09158 & 0.3716 \\
LNSER, LNGS Granger nedeni değildir & 1.73678 & 0.1577 \\
LNGS, LNSER Granger nedeni değildir & 5.45200 & 0.0011 \\
LNIS, LNKI Granger nedeni değildir & 4.53861 & 0.0035 \\
LNKI, LNIS Granger nedeni değildir & 1.59952 & 0.1901 \\
LNSER, LNKI Granger nedeni değildir & 2.87580 & 0.0328 \\
LNKI, LNSER Granger nedeni değildir & 2.47344 & 0.0571
\end{tabular}


LNSER, LNIS Granger nedeni değildir

LNIS, LNSER Granger nedeni değildir
0.64879

2.13332
0.6305

0.0914

Tablo 16' da verilen nedensellik test sonuçları kadın istihdamı ve ekonomik büyüme arasında herhangi bir nedensel ilişkiye rastlanmamıştır. Yalnız anlamlılık seviyesi \%10 olarak baz alınırsa, ekonomik büyümenin kadın istihdamı üzerinde pozitif bir nedensellik ilişkisi olduğu söylenebilir. Bu sonuçları yukarıda tahmin edilen kısa ve uzun dönemli katsayıların verdiği sonuçlarla örtüşür niteliktedir. Çünkü tahmin edilen regresyon sonuçları da kısa dönemde kadın istihdamı ile ekonomik büyüme arasında bir ilişkinin olduğunu göstermiştir. Nedensellik test sonuçları kadın istihdamı ve toplam işgücü arasında tek taraflı bir nedensellik bağı olduğunu, yani toplam işgücündeki artışın kadın istihdamını artırdığını gösterir niteliktedir. Bu noktada beklenen sonuç budur. Çünkü kadın istihdamı arttıkça toplam işgücü miktarı da aratacaktır. Öte yandan yine ekonomik büyüme ile sermaye stoku arasında da tek taraflı bir nedensellik bulunmuştur. Yani ekonomik büyüme sermaye stokunun artmasına neden olmaktadır ki bu da teori ve beklentilerle paralel bir gelişmedir. Sermaye stoku ve kadın istihdamı arasında ise tek taraflı bir nedensellik ilişkisi bulunmuş yani sermaye stokundaki artış kadın istihdamını da artıracaktır.

\section{SONUÇ}

Bu çalışmada Türkiye özelinde kadın işgücünün görünümü analiz edilmiş, ekonomik büyüme ve kadın işgücü arasındaki ilişki ve kadının işgücü piyasasındaki önemi incelenmiştir. Çalışmanın temel amacı olan Türkiye'de kadın istihdamı ile ekonomik büyüme arasındaki uzun dönemli ilişki, ARDL eş bütünleşme testi ve hata düzeltme modeli uygulanarak bulunmuştur. Öncelikle kadın istihdamı ve ekonomik büyüme arasındaki ilişkide uzun dönemli bir eşbütünleşmenin olup olmadığına bakılmıştır. ARDL sınır testi, değişkenler arasında eşbütünleşmenin varlığını ortaya çıkarmıştır. Eşbütünleşmenin varlığı sonucu yine ARDL hata düzeltme modeli kullanılarak kısa ve uzun dönemli tahmin katsayıları bulunmuştur. Analizler, Türkiye'de kadın istihdamı ile ekonomik büyüme arasında kısa dönemde pozitif bir ilişki sunarken, bu ilişkinin uzun dönemde ise negatif olduğunu göstermiştir. Uzun dönem katsayılarına bakıldığında ise yine kadın istihdam ile ekonomik büyüme arasında anlamlı bir ilişki çıkmakta ancak sürpriz bir şekilde bu ilişkinin yönü negatif görülmektedir. Bu durumun ortaya çıkması gayet normal olarak görülebilir, çünkü ekonominin büyüme dönemleri bir döngü içinde ve ekonomik gelişmeleri etkileyen işgücü gibi bazı faktörler ise uzun dönemde bu döngüden farklı bir seyir izleyebilir. Ülkelerin ekonomik gelişmeleri işgücünden bağımsız olarak da bir çok faktörden etkilenebilir. Örneğin teknolojide yaşanan olağanüstü adımlar daha fazla istihdam olmadan büyüme tarafında verimliliği yükseltmiştir ki bu durum toplam işgücü miktarının katsayılarında da kendisini göstermektedir. Her ne kadar uzun dönemde işgücü ile ekonomik büyüme arasında negatif bir ilişki bulunmuşsa da kısa dönemde ekonomik teorilere uygun olarak pozitif ilişkinin varlığı test sonuçları tarafından ortaya çıkarılmıştır. Öte yandan ekonomik büyüme ile sermaye stoğu arasında hem kısa dönemde hem uzun dönemde pozitif bir ilişkinin bulunması kullanılan kaynakların aslında verimlilik artışına sebep olduğunu ve verimlilik artışının da ekonomik büyümeye yol açtığı rahatlıkla söylenebilir. Genel olarak bu çalışmanın sonuçları kısmen literatürün Türkiye örneğinde yapılan çalışmalar, örneğin Günsoy ve Özsoy (2012),Serel ve Özdemir (2017), Zeren ve Savrul (2017) ve Pata (2018) bulunan kadın istihdamı ile ekonomik büyüme arasındaki pozitif ilişkiye paralellik göstermiştir. 


\section{KAYNAKÇA}

Berber, M.\& Eser, B.Y. (2008).Türkiye'de Kadın istihdamı: Ülke ve Bölge Düzeyinde Sektörel Analiz. "İş,Güç” Endüstri İlişkileri ve İnsan Kaynakları Dergisi, Cilt:10, Sayı:2, Nisan 2008.

Brooks, C, (2004). Introductory Econometrics for Finance, (5th edition), Cambridge University Press, Cambridge.

Dedeoğlu, S. (2000). Toplumsal Cinsiyet Rolleri Açısından Türkiye'de Aile ve Kadın Emeği. Toplum ve Bilim, 86, 139170, 2004.

Dickey, D.A. ve Fuller, W.A. (1979). "Distribution of the estimators for autoregressive time series with a unit root", Journal of the American Statistical Association, 74, 427-431, 1979.

DİE, (1996). Çalışma İstatistikleri, Ankara,

Elliott, G. Rothenberg, T. J. And Stock, J. H. (1996) “Efficient Tests for an Autoregressive Unit Root," Econometrica, 64, 4, 813-836, 1996.

Günsoy, G. ve Özsoy, C. (2012) “Türkiye’de Kadın İşgücü, Eğitim ve Büyüme İlişkisinin VAR Analizi” Finans Politik \& Ekonomik Yorumlar. 2012 Cilt: 49 Sayı: 568, 2012.

İğde, G. (2011). “Avrupa Birliği’nde İşv ve Aile Yaşamını Uyumlaştırma Politikaları: İspanya ve Türkiye Örneği”, Yüksek Lisans Tezi, İstanbul Üniversitesi Sosyal Bilimler Enstitüsü, İstanbul, 2011.

Kızılgöl, Ö.A. (2012). Kadınların İşgücüne Katılımının Belirleyicileri: Ekonometrik bir Analiz. Doğuş Üniversitesi Dergisi, Cilt:13, Sayı:1, 2012.

Kuznetz, S. (1973). Modern EconomicGrowth: Findings and Reflections. The American Economic Review, Vol.63, No.3, 247-258, 1973.

Kiatkowski, D., Phillips, P. C. B., Schmidt, P. Shin, Y. (1992). Testing the Null Hypothesis of Stationarity Against the Alternative of a Unit Root. Journal of Econometrics, 54, 159-178, 1992.

Mackinnon, J. G. (1991). Critical Values for CointegrationTests", R. F. Engleand C. W. J. Granger (Eds), Long-Run Economic Relationship: Readings in Cointegration. Oxford UniversityPress, New York, 1991.

Mokyr, J., C. Vickers and N. L. Ziebarth (2015). "The History of Technological Anxiety and the Future of Economic Growth: Is This Time Different?”, The Journal of Economic Perspectives, 31-50, 2015.

Otaran, N., Güven, F. Gürkaynak, İ \& Atakul, S. (2003). Eğitimin Toplumsal Cinsiyet Açısından İncelenmesi, Türkiye 2003. Unicef Türkiye Çalışması, 2003.

Özer, M. \&Biçerli, K. (2003). Türkiye'de Kadın İşgücünün Panel Veri Analizi. Anadolu Üniversitesi Sosyal Bilimler Dergisi, C.: 3,Say1: 1, 2003.

Pata, U.K. (2018). "Türkiye'de Kadın İstihdamı ve Ekonomik Büyüme İlişkisi: Simetrik ve Asimetrik Nedensellik Testleri ile Sektörel bir Analiz" Uluslararası İktisadi ve İdari İncelemeler Dergis, 35 - 150, 2018.

Pesaran, M.H., Shin, Y., and Smith, R.J. (2001). Bounds testing approaches to the analysis of level relationships. Journal of Applied Econometrics, 16 (3), 289-326, 2001.

Peterson, Janice. (2016). "The well-being of working women in times of economic crisis and recovery: Insights from the Great Recession." Handbook on well-being of working women. Springer, Dordrecht, 517-539, 2016.

Phillips, P. C. B. and Perron, P. (1988). "Testing for Unit Roots in Time Series Regression," Biometrika, 75, 335-346, 1988.

Sarı, R., Hammoudeh, S., and Ewing, B. T. (2007). Dynamic Relationships Between Oil and Metal Commodity Futures Prices. Geopolitics of Energy, vol.29 no.17, 2007.

Sayılan, F. (2012). Toplumsal Cinsiyet ve Eğitim: Olanaklar ve Sınırlar. Dipnot Yayınevi, Ankara, 2012.

Serel, H. ve Özdemir, B.S. (2017). "Türkiye'de Kadın istihdamı ve Ekonomik Büyüme İlişkisi” Yönetim ve Ekonomi Araştırmaları Dergisi, Cilt/Volume: 15 Sayı/Issue: 3 Eylül/September 2017, 132-148, 2017.

TÜİK, (2018). İşgücü İstatistikleri, http://www.tuik.gov.tr/PreTablo. do?alt_id=1007 (Erişim: 10.05.2019).

TÜIK (2017). İşgücü İstatistikleri 2017, http://www.tuik.gov.tr/ HbGetirHTML.do?id=24629, Erişim Tarihi: 1 Mayıs 2019.

Zeren, F. ve Savrul, B. K. (2017). "Kadınların İşgücüne Katılım Oranı, Ekonomik Büyüme, İşsizlik Oranı ve Kentleşme Oranı Arasındaki Saklı Koentegrasyon İlişkisinin Araştırılması" Yönetim Bilimleri Dergisi. Cilt / Volume: 15, Sayı / N: 30, 87-103, 2017. 